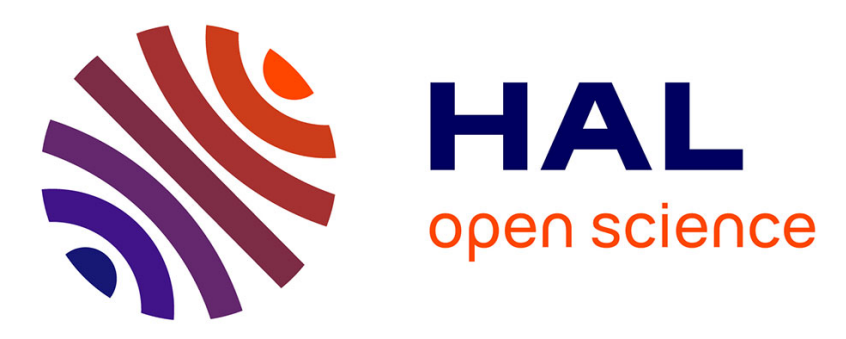

\title{
On Unemployment Inflow and Outflow in Urban China
} Shujie Yao, Zhongmin Wu

\section{To cite this version:}

Shujie Yao, Zhongmin Wu. On Unemployment Inflow and Outflow in Urban China. Regional Studies, 2006, 40 (08), pp.811-822. 10.1080/00343400600660748 . hal-00514620

\section{HAL Id: hal-00514620 \\ https://hal.science/hal-00514620}

Submitted on 3 Sep 2010

HAL is a multi-disciplinary open access archive for the deposit and dissemination of scientific research documents, whether they are published or not. The documents may come from teaching and research institutions in France or abroad, or from public or private research centers.
L'archive ouverte pluridisciplinaire HAL, est destinée au dépôt et à la diffusion de documents scientifiques de niveau recherche, publiés ou non, émanant des établissements d'enseignement et de recherche français ou étrangers, des laboratoires publics ou privés. 


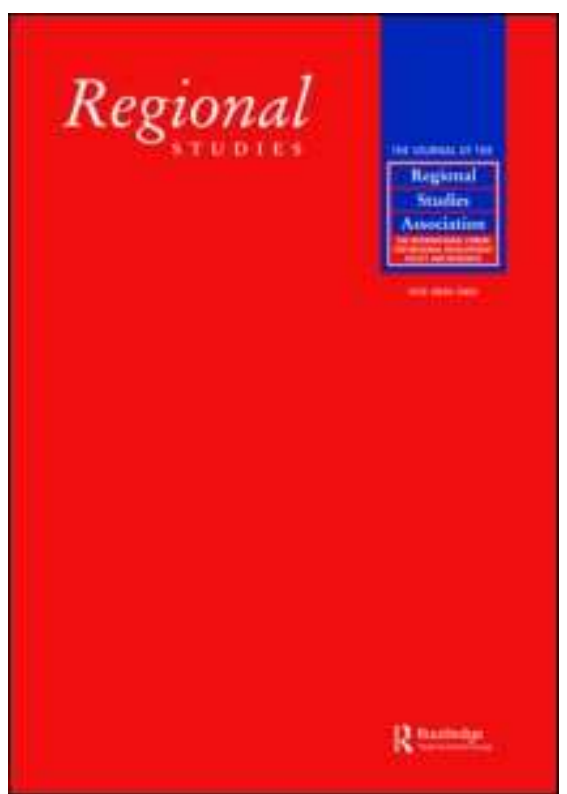

On Unemployment Inflow and Outflow in Urban China

\begin{tabular}{|r|l|}
\hline Journal: & Regional Studies \\
\hline Manuscript ID: & CRES-2004-0008.R2 \\
\hline Manuscript Type: & Main Section \\
\hline JEL codes: & $\begin{array}{l}\text { J61 - Geographic Labor Mobility |Immigrant Workers < J6 - Mobility, } \\
\text { Enemployment, and Vacancies < J - Labor and Demographic } \\
\text { Job Search }<\text { J6 - Mobility, Unemployment, and Vacancies }<\text { J - } \\
\text { Labor and Demographic Economics }\end{array}$ \\
\hline Keywords: & Regional unemployment, China, ownership \\
\hline
\end{tabular}

\section{SCHOLARONE} Manuscripts 


\title{
On Unemployment Inflow and Outflow in Urban China
}

\begin{abstract}
As the largest transitional economy in the world, China's labour market has a number of characteristics distinctively different from that of the developed economies like the UK or the USA. This paper aims to identify the determinants of unemployment inflow and outflow in urban China. With empirical data for 29 provinces over the period 1989-99, it is found that rural-urban migration, ownership diversification, industrial structural change, international trade, international competitiveness, product wages, and age structure are key determinants of unemployment flows. The results suggest that due to market imperfections, unemployment inflow and outflow are two asymmetric processes with respect to the concerned pre-determined variables.

JEL: $\quad$ J64, J61

Key Words: Regional unemployment, Ownership, China
\end{abstract}




\section{Introduction}

There are numerous studies on unemployment inflow and outflow for the developed economies. Nickell (1982) presents a comprehensive study on the UK labour market. He develops an equilibrium unemployment system to identify the key determinants of unemployment inflow and outflow. He suggests that age structure, firing cost, product wages, international competitiveness and job matching are key determinants of unemployment inflow, and that age structure, pressure on the unemployed to accept jobs, replacement ratio, firing cost, industrial structure, product wages, job matching, and international competitiveness are key determinants to unemployment outflow. Some more recent studies, such as Burgess (1993) on unemployment outflow in the UK, Dor, Van der Linden and Lopez-Novella (1997) on unemployment outflow in Belgium, Eriksson and Pehkonen (1998) on unemployment flows in Finland, use different modelling approaches but come to identify a similar set of determinants.

The studies of unemployment flows in transitional economies, especially for China, are few. But due to the special characteristics of the transitional economies, one cannot simply adopt the models that have been applied successfully to the developed economies. In China, for example, a number of special features in its labour market would render the above-mentioned models inappropriate.

The labour market in China is clearly segmented between the rural and the urban areas. In the official statistics, there is no record on rural unemployment. It is assumed that all 
rural labour can either work in the township and village enterprises (TVEs) or in agriculture. In 1978, there were 306 million rural workers and the vast majority of them were engaged in agricultural production. By 2001, the rural labour force rose to 491 million, of which, 131 millions worked in TVEs, 38 million in private non-farm enterprises and the rest in agriculture (NBS, 2002, p120). Many authors estimate that up to $150-200$ millions peasants can be transferred out of agriculture without affecting its total production. These agricultural workers are not considered to be unemployed as they can all in theory engage in some form of agricultural production, albeit at a low or close to zero marginal product. However, this large reservoir of rural workers poses a tremendous pressure on urban employment if they were allowed to move to the cities unchecked.

In the urban sector, employment was predominantly concentrated in the state sector (state-owned units or enterprises) before the inception of economic reforms (Yao, 2004). In 1978, for example, there were 95 million urban employees, and $78.4 \%$ of them worked in the state sector, with all the rest working in the collective sector. The private sector and foreign firms were non-existent (NBS, 1999, p2). By 2001, there were 239 million urban employees, but only $32 \%$ of them worked in the state sector, $5.4 \%$ in the collective sector and all the rest in either the private sector (15\%) or other forms of ownership, mainly foreign-owned firms (NBS, 2002, p120).

Urban employment, especially employment in the state sector, was heavily protected by the government through restricting rural-urban migration and the soft-budget constraints 
before economic reforms (Yao and Zhang, 2001). In recent years, particularly from mid 1990s, the control on rural-urban migration has been gradually relaxed and the softbudget constraints have been gradually removed. Consequently, more rural people moved to the cities to compete for jobs with urban residents. Moreover, state firms are forced to lay off millions of their workers, creating a double-edge sword on the urban labour market.

Before economic reforms, China was a close and centrally planned economy. Some key elements of economic reforms included the opening-up of the country, subjecting domestic firms to international competition (Yao, 2005). In addition, as China has experienced 25 years of rapid economic growth, the industrial structure has changed from that dominated by agriculture to that dominated by manufacturing and services. Real gross domestic product (GDP) per capita in China rose almost six folds from 1978 to 2001. In 1978, agriculture's share in GDP was $28 \%$. By 2001, this was only $15 \%$ (NBS 2002, p51). The structural change at the regional level is even more pronounced. In Guangdong, the most prosperous province of China, for example, agriculture's share in GDP declined from 30\% in 1978 (NBS, 1999, p592) to only 9.4\% by 2001 (NBS, 2002, p59).

Labour market segmentation, the changes in ownership structure and industrial structure, fast economic growth and the opening-up of economy are just some of the many special features in China that do not prevail in any developed economy. It is these special features that distinguish China's labour market and the behaviour of unemployment from 
that of any other economy. However, the basic models that have worked for the developed economies, such as the inflow and outflow models proposed by Nickell (1982) provide a benchmark to the models to be developed in this paper. Some variables that are found to have significant effects in the UK labour market, such as product wages, international competitiveness and age structure should have similar effect on China's labour market. The primary objective of this paper is to construct the unemployment inflow and outflow equations based on the structure of the models that work well in a developed economy but in the meantime incorporate the special features of the Chinese economy.

The rest of this paper is organised as follows. Section II presents the economic background for the theoretical and empirical models. Section III presents two hypotheses and proposes the most suitable empirical models of unemployment inflow and outflow in urban China. Section IV discusses data and regression results. Section V draws conclusions.

\section{Economic reform and urban unemployment}

The modern history of China can be divided into two distinct periods, i.e., the pre-reform and reform periods. The pre-reform period refers to 1949-78. Apart from the Great Leap Forward Movement and the three years of great famine from 1959 to 1961, the living conditions of people were generally much better than in the pre-1949 period. Due to many political struggles, including the Great Leap Forward and the Cultural Revolution (1966-1976), the economy did not perform to its best potential (Lardy, 1983). By 1978, 
after almost three decades of socialist revolution and construction, the vast majority of the rural population was still living in absolute poverty (World Bank, 1997; Yao, 2000).

Economic reforms started from 1978 under the leadership of Deng Xiaoping. The initial reforms were focused on the agricultural sector (Johnson, 1988, and Lin 1988). One key element of agricultural reforms was the household production responsibility system, which allowed farmers to retain a certain proportion of outputs after fulfilling a production quota set by the production team. This reform, reinforced by a few farm product price increases, released enormous energy from the peasantry. Grain output spurred from 305 to 407 million tons, and real per capita rural income doubled in six years over the period 1978-84 (Yao, 2000).

The success of rural reforms enabled China to embark reforms of the state-owned enterprises (SOEs) and the urban economy. Yet, reforming the urban economy was far more difficult and complicated than reforming the agricultural sector. Rural reform had the spontaneous backing and enormous enthusiasm from the peasantry, but urban reform encountered strong resistance from both the party leaders and SOE workers.

\begin{abstract}
In as early as 1980, the Chinese leadership realized that the most difficult problem in the urban economy was the inefficiency of SOEs and their inability to absorb labour from both the urban and rural sectors $(\mathrm{Hu}, 1997)$. Before economic reforms, despite the fast expansion of the industrial sector, China failed to transform its employment structure.
\end{abstract}


Table $1 \quad$ Output and employment structure by sector in China of selected years

\begin{tabular}{l|c|c|c|c|c|c|c|c}
\hline \multirow{2}{*}{ Year } & \multirow{2}{*}{ GDP } & \multicolumn{3}{|c|}{ Structure by sector in $\%$} & & \multicolumn{2}{|c}{ Structure by sector in \% } \\
& & Agriculture & Industry & Service & Employed & Agriculture & Industry & Service \\
\hline 1952 & 67.9 & 50.5 & 20.9 & 28.6 & 207.3 & 83.5 & 7.4 & 9.1 \\
1978 & 362.4 & 28.1 & 48.2 & 23.7 & 401.5 & 70.5 & 17.3 & 12.2 \\
2001 & 9434.6 & 15.2 & 51.2 & 33.6 & 744.3 & 49.7 & 22.5 & 27.8 \\
\hline Notes: & GDP is in billion yuan at current prices. Employment is in million people. \\
Sources: NBS, 2002, p118 for employment, p51 for GDP.
\end{tabular}

Over the period 1952-78, agriculture's output share declined by 22.4 percentage points but its employment share declined by only 13 percentage points. Industry's output share rose by 27.3 percentage points but its employment share rose by only 10 percentage points (Table 1). As a result, the industrial sector not only failed to absorb any rural workers, but also failed to employ all the urban workers. In particular, millions of educated youth were sent to work and be re-educated by poor and semi-poor peasants in the countryside during the Cultural Revolution in order to reduce employment pressure in the urban areas. Peasants were totally prohibited to move out of agriculture and work offfarm or migrate to the cities.

There were two principal reasons for China's failure in transforming its employment structure. One was its industrial strategy, which overemphasized the role of heavy or capital intensive industries. The other was the lack of incentives and low efficiency in SOEs. The state was responsible for all the losses and profits of all SOEs, irrespective of their performance. The State Plan Commission decided what products and how much of them each firm was to produce. The State Commerce Department was responsible for the procurement and sales of all products. The State Price Bureau fixed the prices of inputs 
and products. The State Labour Bureau allocated workers to individual firms. The only incentive and responsibility of firms were to fulfill their production quotas (Hay, et al. 1994).

Apart from the wrong industrial strategy and the problems of SOEs, China did not allow the rural areas to develop off-farm industries. Private enterprises and self-employed firms were forbidden in the cities. As a result, non-agricultural employment was essentially concentrated in the cities, which were largely dominated by SOEs.

Hence, the most important task of urban reforms was first to encourage the development of non-state and non-collective enterprises, and then to reform the SOEs. The state also allowed rural people to seek employment in the cities (Zhao, 1999). The new development policy enabled China to rapidly expand its urban economy and employment. From 1978 to 2001, total urban employment rose from 95 million to 239 million. In the meantime, the employment share of state-owned units declined sharply from $78.3 \%$ to $31.9 \%$. The share of the collective sector also declined, from $21.5 \%$ to $5.4 \%$. The other sector, including many forms of ownership, particularly private enterprises, selfemployed enterprises, foreign-owned enterprises and joint stock companies, was virtually non-existent in 1978, but by 2001, it employed almost two-thirds of the urban workforce (Table 2). 
Table 2 Urban employment structure in selected years

\begin{tabular}{cccccccc}
\hline & $\begin{array}{c}\text { Total } \\
\text { (million) }\end{array}$ & $\begin{array}{c}\text { State } \\
(\text { million })\end{array}$ & $\begin{array}{c}\text { Collective } \\
\text { (million) }\end{array}$ & $\begin{array}{c}\text { Others } \\
(\text { million })\end{array}$ & $\begin{array}{c}\text { State } \\
(\%)\end{array}$ & $\begin{array}{c}\text { Collective } \\
(\%)\end{array}$ & $\begin{array}{c}\text { Others } \\
(\%)\end{array}$ \\
\hline 1978 & 95.1 & 74.5 & 20.5 & 0.1 & 78.3 & 21.5 & 0.2 \\
2001 & 239.4 & 76.4 & 12.9 & 150.1 & 31.9 & 5.4 & 62.7 \\
\hline
\end{tabular}

Sources: NBS, 1999, p.2; 2002, p.117.

As part of China's concerted effort to industrialize the economy, the rural areas were allowed to promote non-farm production. In particular, the rural township and village enterprises (TVEs) and private enterprises were encouraged to employ as many surplus agricultural workers as possible. In 1978, TVEs employed only $9.2 \%$ of the rural labour force and there were no private and self-employed firms (Yao and Liu, 1998; Liang, Chen and Gu, 2002). By 2001, TVEs employed $26.7 \%$ of the rural labour force and the private and self-employed firms employed another 7.8\% (NBS, 2002, p.117). The fast development of TVEs is nothing but phenomenal. Unlike SOEs, the development of TVEs did not receive any state investments. In less than 20 years, they employed twice as many workers as the SOEs and produced more value-added than the SOEs. In sharp contrast, SOEs were once considered to be the backbone of the Chinese economy and absorbed over two-thirds of total state investments for over half a century (Yao and Liu, 1998; Rozelle, 1994).

Despite the development of TVEs in the countryside and the private sectors in the cities, China still faces enormous pressure on urban employment. Due to the ever rising urbanrural earning inequality, a large number of rural workers are migrating to the towns and cities looking for jobs (Zhai and Wang, 2002; Martin and Sunley, 1999). The official 
statistics shows that the total number of rural-urban migrants was 16 millions in 1998 but Wu and Yao (2003) suggest that the actual number could be substantially larger because of underreporting.

In the cities, many SOEs have been making losses for decades (Mao and Higano, 1998). As a result of the withdrawal of state subsidies and the implementation of the bankruptcy law, many firms are closed down, merged or downsized, sending millions of workers out of employment. Appleton et al. (2002) report that as many as $11 \%$ of urban workers have been laid-off in recent years and $53 \%$ of them failed to find alternative employment. However, many of these workers are not classified as unemployed in the official statistics although they are effectively jobless. Laid-off workers are supported by a reduced salary or state subsidies for up to two years until they find alternative jobs. During this period, they are not included in the unemployment statistics. Only after this period are they regarded as unemployed if they still cannot find any jobs.

III. Theoretical models of unemployment flows in urban China The basic model follows Nickell's study on the UK labour market (Nickell, 1982). This model is extended by Junankar and Price (1984). Following Junankar and Price (1984) and bear in mind that our own models will be constructed for panel data instead of time serial data, inflows and outflows at time $\mathrm{t}$ in region $\mathrm{i}$ can be decomposed into $\mathrm{I}_{\mathrm{ti}} \equiv$ inflows $=$ fires + quits + new and re-entrants, and $\mathrm{O}_{\mathrm{ti}} \equiv$ outflow $=$ hires + discouraged 
workers + retirements. The stock of unemployment $U_{\mathrm{it}}$ can be expressed as $\mathrm{U}_{\mathrm{ti}}=\mathrm{U}_{\mathrm{ti}-1}+$ $\left(\mathrm{I}_{\mathrm{ti}}-\mathrm{O}_{\mathrm{ti}}\right)$.

Where unemployment is defined at the end of the period and $\mathrm{I}_{\mathrm{ti}}$ and $\mathrm{O}_{\mathrm{ti}}$ are the flows during the period.

Equations (1) and (2) can be used to estimate inflow and outflow.

$$
\begin{aligned}
& \ln I_{t i}=\alpha_{1} \ln E_{t i-1}+\sum_{j=2}^{n} \alpha_{j} \ln X_{j t i}+\varepsilon_{1 t i} \\
& \ln O_{t i}=\beta_{1} \ln U_{t i-1}+\sum_{k=2}^{m} \beta_{k} \ln Z_{k t i}+\varepsilon_{2 t i}
\end{aligned}
$$

Where $\mathrm{E}$ is total employment, Z's and X's are sets of explanatory variables.

In the literature (e.g. Nickel, 1992; Junankar and Price, 1984; Wickens, 1978), the following variables are found to have significant effects on $\mathrm{I}_{\mathrm{ti}}$ and $\mathrm{O}_{\mathrm{ti}}$.

- $\quad$ product wages, which is defined as the average wages divided by output per worker

- aggregate demand, which is measured as the digression of actual GDP to the trended GDP

- $\quad$ age structure, which is the composition of unemployment stock by different age groups 
- international competitiveness, which measured the export price of the concerned economy in comparison to the rest of the world

- $\quad$ replacement ratio, which is the benefit compensation received by the unemployed as a proportion of their likely post tax income in work

- $\quad$ cost of firing, which is usually represented by the cases of unfair dismissals

- $\quad$ job matching, defined as (vacancies/employment)

- $\quad$ world trade

- $\quad$ pressure to accept jobs, measured as the cases of benefit disqualification

Of the above variables, product wages, aggregate demand, age structure, international competitiveness and world trade can be easily applied to urban China. The other variables are either not available (replacement ratio, pressure to accept jobs, cost of firing), or do not have data to support. In addition, labour market in China has some special characteristics which are not relevant in an industrialised country like the UK. Special features of the Chinese labour market include (1) rural-urban segmentation, (2) ownership structure in the urban industries, (3) rapidly changing economic structure between sectors, and (4) rural farm and non-farm employment structure and wage differentials. All these features may render the established unemployment flow equations inappropriate for China although the underlining theory on the determination of unemployment flows is similar.

To incorporate the special features of the Chinese labour market into the existing models, the following presents two important hypotheses relating to unemployment flows in http://mc.manuscriptcentral.com/cres Email: regional.studies@fm.ru.nl 
urban China. These hypotheses are the basis of the theoretical and empirical models to be developed later.

Hypothesis 1: Urban unemployment is due to high wages, rural migration and population pressure.

This hypothesis can be illustrated in Figure 1 below. Let $\mathrm{S}$ and $\mathrm{D}$ respectively depict the supply and demand curves of labour. If urban wages is fixed at W, supply is greater than demand by (D'-D). In the pre-reform period, SOEs might be forced by the government to employ up to D', and the difference (D'-D) would not be considered to be unemployed but overstaffed (Yin, 2001). After reforms, if firms were allowed to employ the optimal amount of labour, then (D'-D) would become a stock of unemployment if $\mathrm{W}$ is still fixed by the government.

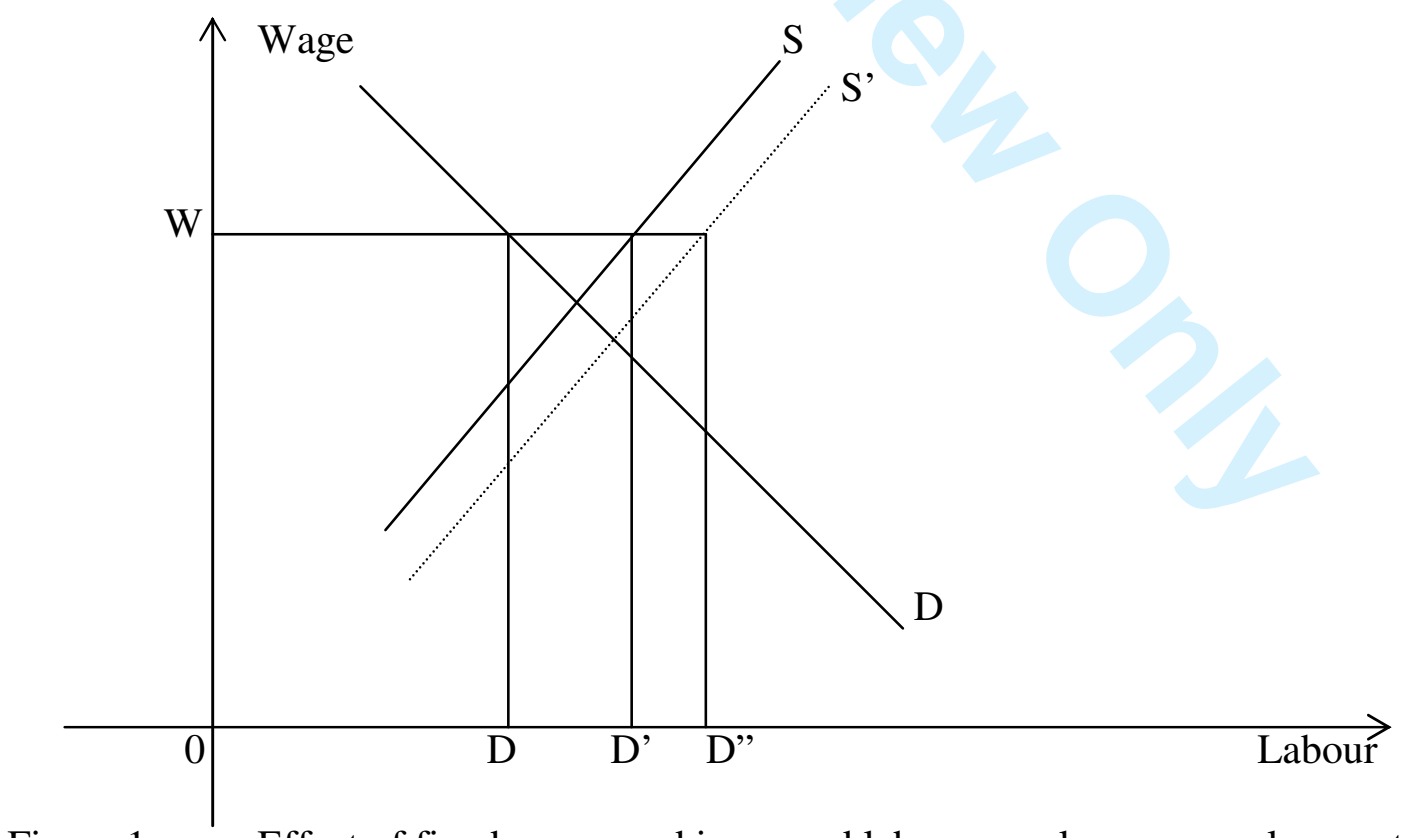

Figure 1 Effect of fixed wages and increased labour supply on unemployment 
Unemployment can increase if there is a supply shift. This shift can be caused by the influx of rural migrants, or population growth in the cities themselves. Assuming the supply curve shifts from $S$ to $S^{\prime}$, without changing the demand curve and the wage rate, total unemployment will rise to (D"-D). Figure 1 implies that unemployment inflow tends to rise if any of the following variables rises: urban wages, rural-to-urban migration and urban population growth.

Hypothesis 2: Ownership diversification and industrial structural change can lead to more employment, or a reduction in unemployment.

\footnotetext{
As mentioned in the previous section, SOEs dominated the urban economy before economic reforms. The development of SOEs followed government's ambitious industrialisation strategy, which overemphasised on large-scale and capital intensive industries. As a result, industrial growth failed to create sufficient employment. Economic reforms have encouraged the development of private and self-employed firms as well as foreign-invested firms (Yin, 1998; Cook and Maurer-Fazio, 1999; Kiyokawa, 2001). Compared to SOEs, the non-state enterprises are more labour intensive and efficient. As a result, they can create more jobs than the SOEs for a given amount of capital investment.
} 


\section{Capital}

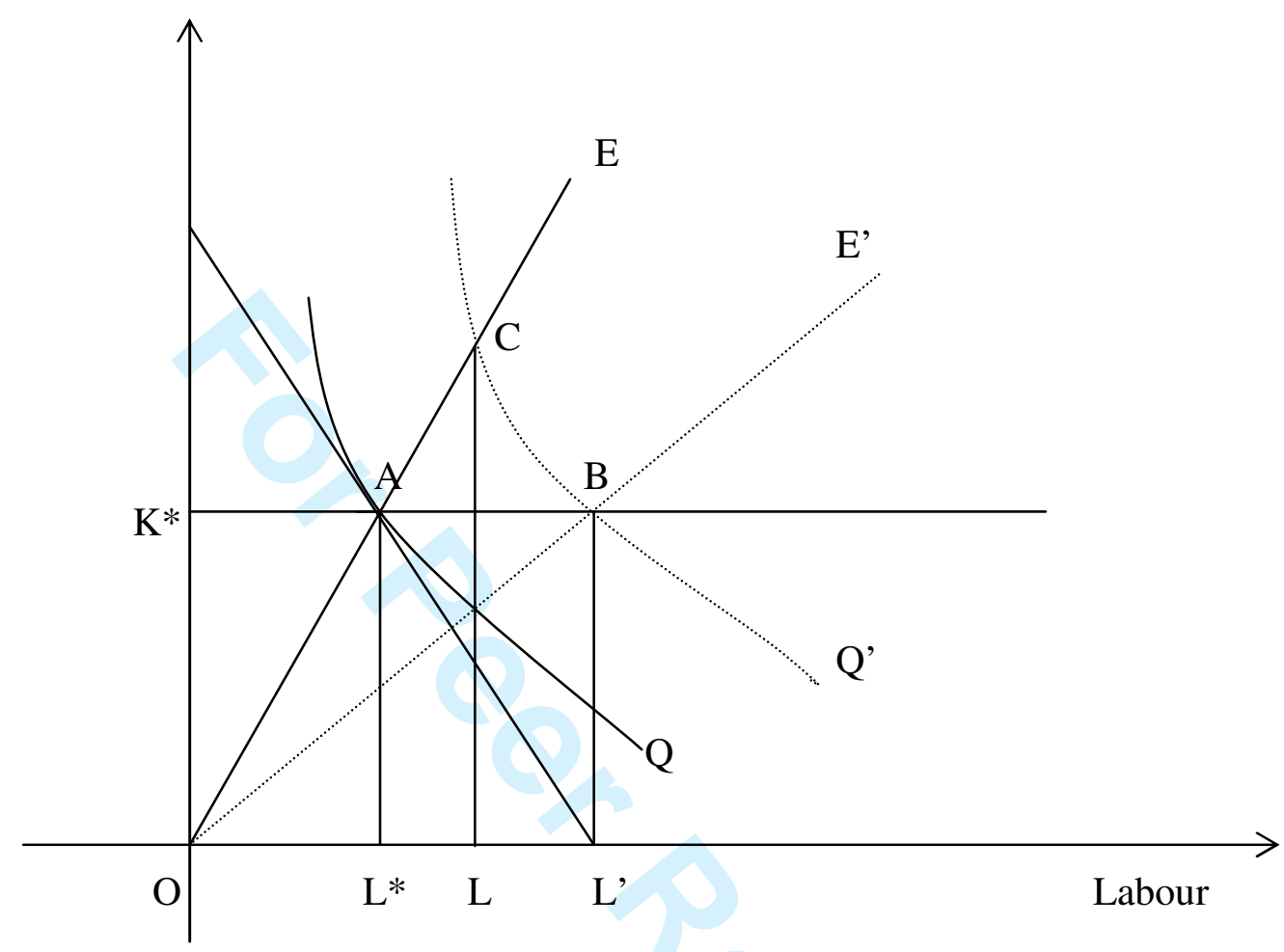

Figure 2 Industrial/ownership structure and unemployment

The change in industrial structure can have a similar effect. For example, the urban economy was over-dominated by industries before economic reforms. The services sector was undermined as it was considered to create no value-added for the economy based on the interpretation of the leadership on Marx's economic theory. After economic reforms, the services industries were recognised as a production sector and believed to create value-added for the economy. The relative shift from manufacturing to services implies that for the same amount of investment, more jobs can be created. ${ }^{1}$

\footnotetext{
${ }^{1}$ Industrial structural change refers to change from agriculture to non-agricultural sectors, and change from manufacturing to services. This change will lead to more job creation in the urban economy for a given amount of aggregate investment. Ownership diversification refers to change from state-owned to non-state owned industries, causing two positive effects on urban employment. First, non-state firms will be more efficient than state firms in job creation given the same capital/labour structure. Non-state firms tend to be more labour-intensive than state firms, hence more jobs will be created for the same amount of investment.
} 
Figure 2 illustrates the effect of ownership diversification and industrial structural change on employment. Prior to diversification and structural change, the urban economy follows the expansion path OE. When capital is fixed at $\mathrm{K}^{*}$, total employment is $\mathrm{L}^{*}$. To create more jobs, more capital has to be invested along OE. However, with diversification and structural change, the expansion path may shift from OE to OE'. Without making more investment, more jobs could be created. The extra jobs would be equal to (L'- $\left.\mathrm{L}^{*}\right)$.

Hypothesis 2 implies that unemployment will be reduced if any of the following variables rises: the share of the private sector and the share of the services sector in the economy.

To testify the above hypotheses, we need to develop the unemployment inflow and outflow equations. Following Junankar and Price (1984), unemployment inflow and outflow can be decomposed as follows.

It needs to be stressed that the above two hypotheses have simplified the labour market in China as they only consider the key factors that may lead to changes in unemployment flows. There are certainly other factors that may be relevant but not included in the hypotheses. For instance, the growth of the urban economy must be also another important factor. However, this variable can be treated as a fixed and 'exogenous' variable in the model so that we focus on the variables that are more closely related to government policy, such as those considered in the hypotheses. 
To account for the reality in China and incorporate the hypotheses made earlier, the following variables are considered to be relevant.

(1) Real product wages

This is measured as the average workers and staff wages as a proportion of GDP per worker in the industrial sector. In the literature, it is expected that this variable will have a positive effect on inflow and a negative effect on outflow.

(2) Youth unemployment as a proportion of total unemployment

This is like an age composition variable, but it reflects more on the intrinsic nature of the labour market in urban China. In the past, as every working-age person would be assigned a job irrespective of his/her age, sex, or education. Hence, urban unemployment largely comprised of school leavers aged between 16-25, contract and temporary workers. However, $\mathrm{Fu}$ et al. report that there was a surprisingly high incidence of unemployment among permanent state employees in as early as 1989 in China's largest industrial city, Shanghai (Fu, et al., 1993). The likely effect of this variable has little economic meaning but it is important to include it in the equations as a control variable.

(3) Ownership diversification 
This variable can be represented by the industrial output shares of three different ownership: state, collective and private. ${ }^{2}$ The state sector includes SOEs and other stateowned units. The collective sector includes firms owned by the local or street-level governments. The private sector includes private enterprises, self-employed, foreignowned enterprises and joint stock companies. If Hypothesis 2 is true, it is expected that the output share of the private sector will have a positive effect on outflow and a negative effect on inflow. The output share of the state sector should have an opposite effect.

\section{(4) Industrial structure}

This variable can be represented by the GDP shares of three different sectors: agriculture, industry and services. If Hypothesis 2 is true, it is expected that the output share of the services sector will have a positive effect on outflow and a negative effect on inflow. The output share of industry may have a similar effect, but it will not be surprising if it does not, as it has been discussed above that the services sector is more labour-intensive than the industrial sector.

\section{Rural-urban migration}

The migration data are not accurate, but it is possible to use agriculture's employment share in total employment as an indicator of migration pressure. It is expected that the higher this share, the greater the pressure on urban employment will be. Hence, it is

\footnotetext{
${ }^{2}$. The official statistics only reports industrial outputs by ownership. As a result, we can only use the industrial output shares to represent the relative importance of different ownership forms in the economy.
} 
expected to have a positive effect on inflow and a negative effect on outflow. The ratio of per capita rural income over average urban wages can also represent migration pressure, as it is expected that the greater the rural/urban earning gap, the more incentive of rural people to move to the cities (Knight and Song, 1995; Dong, 1998; Meng, 1996).

Rural-urban migration takes place in two forms: rural-urban migration in the same region and inter-regional migration. As a result, inter-regional income inequality should also play a role in the determination of migration. However, the within region agricultural employment shares and per capita rural income over average urban wages can actually reflect the inter-regional income inequality, as poorer regions tend to have a higher agricultural labour shares and lower rural income/urban wages ratios. Hence, it is not necessary to include an inter-regional income inequality variable in the model to be a driver of migration.

(6) International trade

International trade is used as the ratio of total trade over GDP. The effect of this variable on employment may not be clear. Reynolds (1987) finds controversial evidences of trade on employment in the same study. He shows that trade reduced employment in 1981, but raised employment in 1985 . Other authors argue that trade can stimulate growth and hence could lead to more employment. However, Xu and Chang (2000) find that tariff reduction to promote trade has a negative effect on employment although the effect is not serious. Zhai and Wang (2002) find that China's accession to the World Trade 
Organisation (WTO) may increase trade with the rest of the world, but it can also lead to more urban unemployment.

(7) International competitiveness

This is measured by the real effective exchange rate. The real effective exchange rate is calculated by using the official exchange rate adjusted by the consumer price index (CPI) prevailing in the US and China over the data period. As it is measured in terms of yuan $/ \$$, this variable reflects the competitiveness of China's exports. Hence, it is expected to have a positive effect on outflow and a negative effect on inflow.

Our empirical models for urban China are defined in equations (3) and (4).

$$
\begin{aligned}
\ln I R_{t i}= & \alpha_{0}+\alpha_{1} \ln U R_{t i-1}+\alpha_{2} \ln O U T_{-} P S_{t i-1}+\alpha_{3} \ln O U T_{-} S S_{t i-1}+\alpha_{4} \ln E M P_{-} A S_{t i}+ \\
& \alpha_{5} \ln A G E 1625_{t i}+\alpha_{6} \ln G D P_{-} I S_{t i}+\alpha_{7} \ln G D P_{-} T S_{t i}+\alpha_{8} \ln \left(T_{r a d e} / G D P\right)_{t i}+ \\
& \alpha_{9} \ln R U R_{t i}+\alpha_{10} \ln R E E R_{t i}+\alpha_{11} \ln P W A G E_{t i} \\
\ln O R_{t i}= & \beta_{0}+\beta_{1} \ln U R_{t i-1}+\beta_{2} \ln O U T_{-} P S_{t i-1}+\beta_{3} \ln O U T_{-} S S_{t i-1}+\beta_{4} \ln E M P \_A S_{t i}+ \\
& \beta_{5} \ln A G E 1625_{t i}+\beta_{6} \ln G D P_{-} I S_{t i}+\beta_{7} \ln G D P_{-} T S_{t i}+\beta_{8} \ln (T r a d e / G D P)_{t i}+ \\
& \beta_{9} \ln R U R_{t i}+\beta_{10} \ln R E E R_{t i}+\beta_{11} \ln P W A G E_{t i}
\end{aligned}
$$

In the equations, $\alpha$ 's and $\beta$ 's are parameters to be estimated, $t$ and $i$ denote year $t$ and region i. The definitions of all dependent and explanatory variables are given in Table 3.

Table 3 Definitions of dependent and explanatory variables

\begin{tabular}{|l|l|}
\hline IR & Urban unemployment inflow/urban employment \\
\hline OR & Urban unemployment outflow/urban employment \\
\hline
\end{tabular}




\begin{tabular}{|c|c|}
\hline UR & Urban unemployment/urban labour force \\
\hline OUT_PS & Industrial output share by the private sector \\
\hline OUT_SS & Industrial output share by the state sector \\
\hline EMP_AS & Agricultural employment/total rural plus urban employment \\
\hline AGE1625 & Urban unemployment aged 16 to $25 /$ total urban unemployment \\
\hline GDP_IS & GDP share by the industrial sector \\
\hline GDP_TS & GDP share by the tertiary (service) sector \\
\hline TRADE/GDP & Exports+Imports/GDP \\
\hline RUR & Rural per capita income/urban average wage rate of staff and workers \\
\hline REER & $\begin{array}{l}\text { Real effective exchange rate }=\text { official exchange rate } \\
(\text { yuan/\$)*(CPI } \\
\left.\text { USA } / C P I_{\text {China }}\right), \mathrm{CPI}=\text { Consumer price index }\end{array}$ \\
\hline PWAGE & Average wages of staff\&worker/GDP per worker in industrial sector \\
\hline
\end{tabular}

IV. Data and regression results

\section{IV.1 Data}

The regression models use a panel data set for the period 1989-99 based on 29 provinces in urban China. There are 31 cities (with provincial status), provinces and autonomous regions in China. For simplicity, they are called provinces, or regions. Due to data inconsistency and inadequacy, Tibet cannot be included. Chongqing became a provincial level city from 1997 but the data period started from 1989. For consistency, Sichuan and Chongqing are still treated as one province. With 11 years, there are 319 data points. Because three variables are lagged by one period, the actual data points are 290. The summary statistics of the variables are given in Table 4. 
Table 4 Summary statistics of dependent and independent variables (319 observations)

\begin{tabular}{lllll}
\hline & Mean & Std Dev & Min & Max \\
\hline Inflow rate IR (\%) & 3.23 & 1.13 & 0.83 & 7.64 \\
Outflow rate OR (\%) & 3.04 & 1.01 & 0.79 & 5.99 \\
Unemployment rate UR(-1)(\%) & 2.83 & 1.28 & 0.35 & 7.71 \\
Industry output share by private sector, OUT_PS(\%) & 16.46 & 12.1 & 1.91 & 56.4 \\
Industry output share by state sector, OUT_SS (\%) & 55.04 & 19.1 & 9.41 & 84.72 \\
Agricultural employment share, EMP_AS (\%) & 53.23 & 17.1 & 8.98 & 78.24 \\
Youth unemployment share, AGE1625 (\%) & 72.00 & 17.6 & 17.04 & 99.86 \\
Share of GDP by industry, GDP_IS (\%) & 43.66 & 8.48 & 19.63 & 66.32 \\
Share of GDP by services, GDP_SS (\%) & 33.35 & 5.15 & 21.10 & 57.34 \\
Trade/GDP ratio (\%) & 21.40 & 25.1 & 2.96 & 165.2 \\
Rural income/urban wage ratio, RWR (\%) & 33.52 & 9.75 & 16.15 & 80.62 \\
Real effective exchange rate, REER (yuan/\$) & 5.189 & 0.66 & 3.65 & 6.540 \\
Product wage, PWAGE & 0.310 & 0.08 & 0.16 & 0.618 \\
\hline
\end{tabular}

Sources: NBS (1989-2002), China Labour Statistical Yearbook, NBS (1989-2001), China Statistical Yearbook.

When running the regressions, it is important to see whether the variables are cointegrated. However, because all the variables are measured in shares or percentage, it is unlikely that they are non-stationary. If all the variables are stationary, the regression results will not be spurious. To make sure this is the case, panel unit root tests are conducted for all variables. It is found that apart from the trade/GDP ratio, which has weak evidence (at the $10 \%$ significance level) of non-stationarity, all the other variables are stationary. A panel cointegration test is also conducted for both models, using the process proposed by Petroni (1999). No evidence is found to reject the hypothesis of no cointegration.

With results from the panel unit root and panel cointegration tests, the models are run with OLS, GLS with fixed effect and GLS with random effect. The Hausman tests suggest that the fixed-effect results are the most appropriate for the unemployment inflow 
equation without year dummies. For the unemployment outflow equation, the fixed effect model with year dummies produces the best results.

\section{IV.2 Regression results and interpretations}

Regression results from the unemployment inflow equation are presented in Table 5. Before discussing the results in detail it is worth noting the coefficients on the GDP shares by industry and services. These two coefficients are not statistically significant, implying that the change in industrial structure may not have any effect on inflow. The result does not support Hypothesis 2 discussed in section III. However, if attention is paid to the coefficients on the industrial output shares of the private and state sectors, Hypothesis 2 is strongly supported as the coefficients have the correct signs and are highly significant. Hence, it may be concluded that ownership structural change is more important than industrial structural change on unemployment inflow. The regression results are consistent with Yin's finding that private enterprises provide a significant alternative employment outlet to laid-off SOEs workers and new entrants to the labour market in urban China (Yin, 2001). 
Table 5 Dependent variable: ln(inflow/urban employment) ti $_{1}$ 1989-99

\begin{tabular}{|c|c|c|}
\hline Independent variables & Coefficients & $\overline{\mathrm{t} \text {-values }}$ \\
\hline$\overline{\ln (\text { Unemployment rate })_{\mathrm{t}-1}}$ & 0.146 & 2.61 \\
\hline $\ln$ (private sector industry output share) & -0.120 & -3.18 \\
\hline $\ln ($ state sector industry output share) & -0.037 & -0.40 \\
\hline $\ln$ (agricultural employment share) & 0.910 & 2.54 \\
\hline $\ln ($ youth aged $16-25$ share in unemployment) & -0.210 & -2.99 \\
\hline $\ln ($ Industry's GDP share) & -0.017 & -0.09 \\
\hline $\ln ($ Service sector GDP share) & 0.158 & 0.79 \\
\hline $\ln ($ Trade/GDP $)$ & 0.123 & 2.40 \\
\hline $\ln$ (per capita rural income/average staff\&worker wages) & -0.176 & -1.95 \\
\hline $\ln ($ Real effective exchange rate) & -0.485 & -3.75 \\
\hline $\ln$ (Average staff wages/GDP per worker in industry) & 0.020 & 0.18 \\
\hline Constant & -0.634 & -0.37 \\
\hline Provincial dummies & Yes & \\
\hline $\mathrm{R}^{2}$ & 0.62 & \\
\hline Number of observations & 319 & \\
\hline Prob $>$ F & 0.00 & \\
\hline Hausman test, Prob $>\chi^{2}$ & 0.00 & \\
\hline
\end{tabular}

Notes: Results are obtained from GLS regression with fixed effect.

Sources: Data are derived from NBS (1989-2002), China Labour Statistical Yearbook; NBS (1989-2002), China

Statistical Yearbook.

The sign and size of the coefficient on the industrial output share of the private sector implies that the development and growth of this sector was helping China to reduce urban unemployment. It also implies that by moving away from the state sector, the urban economy became more efficient as far as job creation is concerned. A $10 \%$ rise in the industrial output share of the private sector could have led to $1.2 \%$ reduction in unemployment inflow.

\begin{abstract}
A second interesting result is the coefficients on the agricultural employment share and the ratio of rural per capita income over average urban wages. The former has a positive sign and is significant. It implies that if a region has a higher share of agricultural employment, there will be more pressure on urban employment as more people will move
\end{abstract}


to the cities to compete for jobs. The sign of the latter is opposite but also significant. This means that the larger the income gap between rural income and urban wages, the more incentives the rural people will have to migrate to the cities. Hence, both variables have the same effect, which is similar to what would have been expected from ruralurban migration. The results support Hypothesis 1 presented in section III.

\begin{abstract}
Another interesting result is the coefficient on the trade variable. It is positive and significant, implying that international trade may lead to less employment although one may expect otherwise. However, if the coefficient on the real effective exchange rate is also considered, the picture is somewhat different. What the latter coefficient suggests is that increased international competition (a higher exchange rate) can lead to more employment, which may cancel out the negative effect of trade. One possible interpretation for these two variables may be that trade may reduce employment if it is not focused on China's competitiveness. However, if China trades with strong competitiveness, it is possible to create more domestic jobs, instead of destroying them.
\end{abstract}

\begin{abstract}
It is worth noting that international trade in China is highly concentrated in the coastal region such as Guangdong, Shanghai, Jiangsu and Zhejiang. As a result, the impact of trade on employment may be uneven cross regions. As the coastal provinces have grown fast due to their dominant position in trade and absorption of FDI, trade may be beneficial for job creation in these regions at the expense of employment in their inland counterparts. The regression results may just reflect the counterbalanced effects of trade on employment across different regions.
\end{abstract}


The signs and significance of the coefficients on the lagged urban unemployment rate and the youth unemployment share are as expected. A higher unemployment rate in the previous year tended to induce higher inflow in the current year. In a region where unemployment is more dominated by the youth, inflow will be less as it may indicate a better labour market for the older aged groups. However, the coefficient on product wages is not significant although it has the correct sign. This means that product wages do not affect inflow. One possible explanation for this is that the labour market in urban China is not perfectly competitive. Another explanation is probably the underreporting of inflow as a large proportion of recently laid-off SOE workers is not included in the official unemployment statistics. The main reason for SOEs laying-off workers is their relatively high wages as suggested in Figure 1 where Hypothesis 1 is presented. As a result, there should have been a positive relationship between staff/worker wages with the number of redundancies. But if many of the SOEs redundancies are not classified as unemployed, it is not surprising to find an insignificant coefficient on the wages variable.

Turning to the regression of the outflow equation in Table 6, several interesting results are observed. First, all the coefficients of four structural variables, the industrial output shares of the private and state sectors, and the GDP shares of the industry and services sectors, have the correct signs and three of them are significant, providing strong and consistent evidence to support Hypothesis 2 in section III. In particular, the industrial output share of the private sector has a significant push effect on outflow but that of the state sector has a significant pull effect. The GDP share of the services sector also has a 
significant push effect, but that of the industry sector is not significant. The signs and significance of these four variables suggest that ownership diversification and industrial structural changes are important for unemployment reduction.

Table 6 Dependent variable: $\ln (\text { outflow/urban employment) })_{\mathrm{ti}}, 1989-99$

\begin{tabular}{lcc}
\hline Independent variables & Coefficients & t-values \\
\hline $\ln ($ Unemployment rate)t-1 & -0.050 & -1.00 \\
$\ln$ (private sector industry output share) & 0.166 & 3.31 \\
$\ln ($ state sector industry output share) & -0.238 & -2.82 \\
$\ln ($ agricultural employment share) & 0.457 & 1.18 \\
$\ln ($ youth aged 16-25 share in unemployment) & -0.119 & -1.81 \\
$\ln$ (Industry's GDP share) & -0.032 & -0.18 \\
$\ln ($ Service sector GDP share) & 0.770 & 4.12 \\
$\ln ($ Trade/GDP) & 0.054 & 1.17 \\
$\ln$ (per capita rural income/average staff\&worker wages) & -0.310 & -1.38 \\
$\ln ($ Average staff wages/GDP per worker in industry) & -0.246 & -2.63 \\
Year dummies & Yes & Yes \\
Constant & -2.060 & -1.27 \\
Provincial dummies & & Yes \\
$\mathrm{R}^{2}$ & 0.55 & \\
Number of observations & 319 & \\
Prob $>$ F & 0.00 & \\
Huasman test, Prob $>\chi^{2}$ & 0.00 & \\
\hline
\end{tabular}

Notes: Results are obtained from GLS regression with fixed effect.

Sources: Data are derived from NBS (1989-2002), China Labour Statistical Yearbook; NBS (1989-2002), China Statistical Yearbook.

Second, the coefficients of agricultural employment share and the ratio of rural income over urban wages have the wrong signs although they are not significant. The results imply that these two variables, which represent the pressure of rural-urban migration on urban employment, do not have a significant effect on outflow although they are found to have a significant effect on inflow in Table 5. Comparing the results from both the inflow and outflow equations, it can be concluded that rural-urban migration has an asymmetric effect on urban employment. Rural migrants compete for urban jobs, forcing urban workers into unemployment. However, the outflow of urban unemployed workers into 
employment may be restricted to a certain group of people, particularly the urban youth, or the newly unemployed who are entitled to some special government re-employment or training schemes. Hence, migration pressure does not necessarily block the urban unemployed to flow out although it can create more inflow.

Third, the product wages is found to have a negative and significant effect on outflow. The result implies that higher wages is a deterrent to outflow and job creation, supporting Hypothesis 1 presented in section III. As this variable is not significant in the inflow equation, there is further evidence of asymmetric behaviour of the urban labour market. Since wages and state sector employment are heavily influenced or regulated by government policies, the level of wages may not affect inflow. However, it is reasonable that firms are reluctant to employ the unemployed for the same wages. Given wages rigidity, the outcome is that higher wages naturally deter outflow.

Finally, in the outflow equation, the real effective exchange rate is omitted due to its close relation with year dummies, but the trade variable is still included. The coefficient on the trade variable, however, is not significant, implying that it may not have any effect on outflow although it was found to have a positive effect on inflow. Hence, the net effect of trade is still employment reduction. The coefficient of the lagged unemployment rate is also insignificant. Hence, it may suggest that the outflow rate does not depend on the level of unemployment in the previous year. The youth unemployment share is negative, implying that outflow is lower in the region where youth unemployment is more dominant. 


\section{Conclusions}

Before drawing any conclusions, it is important to stress that there is a data limitation in this paper. China has laid-off over 20 millions of SOEs workers in recent years, but many of them are not included in the official unemployment statistics. In addition, official unemployment statistics does not include rural migrants. As a result, the urban unemployment rate is likely to be underestimated.

Bearing in mind the data limitation, the results presented in this paper should be interpreted with due caution. Nonetheless, since this paper is probably the first attempt in the literature to establish the unemployment inflow and outflow equations using the best possible data set and identifying all the possible explanatory variables, the empirical evidence is important for understanding the labour market in urban China. The regression results are consistent with theoretical expectation and provide undeniable evidence, supporting the two hypotheses set up in this paper, that is, urban unemployment is caused by higher wages and rural migration (Hypothesis 1) and ownership diversification and industrial structural change are key to urban job creation (Hypothesis 2). There is also evidence that urban unemployment inflow and outflow are two asymmetric processes due to labour market imperfections.

In more detail, ownership diversification is featured with the private sector in the urban economy. This sector has a consistent and significant effect on both unemployment 
inflow and outflow, leading to an overall rise in urban employment. The state sector plays an opposite role, explaining why it has been giving its way to the private sector in the post reform period. The structural change is also important for job creation, although it tends to have a less profound effect than does the ownership shift.

It is worth pointing out that ownership diversification and industrial structural changes may be correlated although they tend to have similar effects on urban employment. For instance, diversification away from state to non-state industries may be correlated with an industrial structural shift away from capital-intensive manufacturing to labour-intensive services. If there is a close relationship between these two processes, it will be difficult to separate their individual effects on urban employment. On the other hand, the positive effect of ownership diversification on employment can also be explained by an efficiency gain induced by non-state ownership.

The effects of trade and international competitiveness on urban unemployment are also interesting. In the literature, the effect of trade on domestic employment has been debatable. Although there is evidence that trade can promote output and employment, there is evidence of an opposite effect. In this paper, if trade were examined in isolation, it would appear to have a negative impact on employment. However, if it were to be considered with international competitiveness, the conclusion may not be negative. It appears that if trade is done through taking China's competitive advantage, it may well have a positive effect on job creation. 
There are a few variables that appear to have asymmetric effect on urban unemployment inflow and outflow. These include the product wages, industrial structural changes, trade, agricultural employment share and rural/urban wage differential. Although all these variables have the expected effects to support the two hypotheses presented in this paper, they do not have the same expected effects in both equations. The asymmetric behaviour of unemployment inflow and outflow is best explained by market imperfections caused by government policies, which are still typical of a planned economy. Hence, it can be concluded that China's transition to a free market economy may still need some considerably more time. 


\section{References}

Appleton, S; Knight, J.; Song, L.; and Xia, Q. (2002) Labour retrenchment in China: determinants and consequences, China Economic Review, 13(2-3):252-75.

Burgess S. M. (1993) A model of competition between unemployed and employed job searchers: an application to the unemployment outflow rate in Britain, The Economic Journal 103: 1190-1204.

Cook, S.; and Maurer-Fazio, M. (1999) Introduction: the workers' state meete the market: labour in China's transition, Journal of Development Studies, 35 (3):1-15.

Dong, Xiaoyuan (1998) Employment and wage determination in China's rural industry: investigation using 1984-1990 panel data, Journal of Comparative Economics, 26(3):485-501.

Dor, E.; Linden, B. V. and Lopez-Novella, M. (1997) On labour market policies and aggregate unemployment outflows, Oxford Bulletin of Economics and Statistics 59(1): 109-131.

Eriksson, T. and Pehkonen, J. (1998) Unemployment flows in Finland, 1969-95: a time series analysis, Labour 12(3): 571-593.

Fu, Gangzhan; Hussain, A.; Pudney, S.; and Wang, Limin (1993) Unemployment in urban China: an analysis of survey data from Shanghai, Labour, 7(1):93-123.

Hay, Donald, Morris, Derek, Liu, Guy, and Yao, Shujie (1994) Economic reform and state-owned enterprises in China 1979-89, Oxford: Clarendon Press.

$\mathrm{Hu}$, Zuliu (1997) Social protection and enterprise reform: the case of China, Enterprise and Social Benefits after Communism, Cambridge University Press.

Johnson, D. G. (1988) 'Economic reforms in the People's Republic of China', Economic Development and Cultural Change, April, p.S225-45.

Junankar. P. N. and Price, S. (1984) The dynamic of unemployment: structural change and unemployment flows, The Economic Journal 94(0): 158-165.

Kiyokawa, Yukihito (2001) Marketization with serious increase of unemployment and the changes in job-consciousness: an analysis of panel survey data in china (In Japanese with English abstract), Economic Review (Japanese), 52(1):72-93.

Knight, John and Song, Lina (1995) Towards a labour market in China, Oxford Review of Economic Policy 11(4): 97-117. 
Lardy, N. (1983) Agriculture in China's modern economic development (Cambridge, Cambridge University Press).

Liang, Zai; Chen, Yiu Por; and Gu, Yanmin (2002) Rural industrialisation and internal migration in China, Urban Studies, 39(12):2175-87.

Lin, Justin Yifu (1988) 'The household responsibility system in China's agricultural reform: a theoretical and empirical study' Economic Development and Cultural Change, April, p.S199-224.

Mao, Guoping and Higano, Yoshiro (1998) Measurement of concealed unemployment in Shanghai, International Regional Science Review 21(1): 59-78.

Martin, R. and Sunley, P. (1999) Unemployment flow regimes and regional unemployment disparities, Environment and Planning A 31(3): 523-550.

Meng Xin (1996) An examination of wage determination in Chinas rural industrial sector, Applied Economics 28: 715-724

Nickell, S. (1982) The determinants of equilibrium unemployment in Britain, The Economic Journal, 92: 555-575.

National Bureau of Statistics (NBS, 1989-2002) China Statistical Yearbook, various issues (Beijing, Statistical Press of China).

National Bureau of Statistics (NBS, 1989-2002) China Labour Statistical Yearbook, various issues (Beijing, Statistical Press of China).

Pedroni, P. (1999) 'Critical values for cointegration test in heterogeneous panels with multiple regressors', Oxford Bulletin of Economics and Statistics, 61(0), Special Issue, November, 653-70.

Reynolds, B. L. (1987) Trade, employment and inequality in postreform China, Journal of Comparative Economics, 11(3):479-89.

Rozelle, S. (1994) Rural industrialisation and increasing inequality: emerging patterns in China's reforming economy, Journal of Comparative Economics, 19:362-91.

World Bank (1997) Sharing rising incomes: disparities in China.

$\mathrm{Wu}$, Zhongmin and Yao, Shujie (2003) Inter-migration and intra-migration in China, a theoretical and empirical analysis, China Economic Review, 14, 371-85.

$\mathrm{Xu}$, Dianqing; Chang Gene H. (2000) Impact of tariff reduction on structural employment in China: a computable general equilibrium analysis, Pacific Economic Review, 5(2):157-67. 
Yao, Shujie and Liu, Jirui (1998) 'Economic reforms and spatial income inequality in China', Regional Studies, Vol.32(8):735-46.

Yao, Shujie (2000) Economic development and poverty alleviation in China under economic reforms, Economic Development and Cultural Change 48(3):447-474.

Shujie Yao and Zongyi Zhang (2001) On regional inequality and diverging clubs: a case study of contemporary China, Journal of Comparative Economics, 29 (3):466-84.

Shujie Yao (2004), Urban unemployment and poverty, a case study of Guangzhou and Tianjin, Journal of International Development, 16(1):171-88.

Shujie Yao (2005) On Economic growth, FDI and exports in China under economic reforms, Applied Economics, forthcoming.

Wickens, M.R. (1978) An econometric model of labour turnover in UK manufacturing industries, Review of Economic Studies, 45, 469-77.

Yin, Xiangkang (1998) The macroeconomic effects of waiting workers in the Chinese economy, Journal of Comparative Economics 26: 150 -164.

Yin, Xiangkang (2001) A dynamic analysis of overstaff in China's state-owned enterprises, Journal of Development Economics, 66(1):87-99.

Zhai, Fan; and Wang, Zhi (2002) WTO accession, rural labour migration and urban unemployment in China, Urban Studies, 39(12):2199-2217.

Zhao, Yaohui (1999) Labour migration and earnings differences: the case of rural China, Economic Development and Cultural Change, 48(4) 767-782. 